\title{
The Tradition of Recycling Identity in Native Culture: The Re-Traditioning of Tradition
}

Our tribe is Yaqui, or Yoeme, or Hiaki Yoeme. Our traditional language is known as Yoemem; it is connected to the Uto-Aztecan language families that encompasses, among others, the O'odham, Tarahumara, Pima, Mayo and Huichol peoples of the Sonoran Desert regions of North and Central America. There are songs and dances that are shared between some of these language families that frequently contain images of the natural world, such as moths, flowers, deer, or mountains - elements that evoke connection in order to encourage the restoration of wellness and healing through telling stories of cycles of life. For our tribe, these are the songs and dances that one hears most often at ceremony. Repeating and rhythmic, growing up from the landscape, these songs and dances are the ones that call us home.

As is common for most tribal names, ours translates in one manner or another as 'the people'. In our original instructions, we are born of the sun as descendants of the Surem, the first people. The Surem lived in sacred stewardship and relationship with the land, a small, quiet people who lived by instincts and closeness to all living things. Sun father gave them the language to speak directly with all elements, as they spoke in the sound of creation. One day the wind carried a new sound that lead to a tree that was vibrating, buzzing. Being that it was a new sound, there was no understanding until a young one came forward, able to understand the language. The tree told of the future to come and gave council of a coming new world. The Surem divided then; some of them choose not to walk into the coming future and instead began to walk back in time to where they were created, becoming mountains, rivers, the sea, the clouds and living in the embrace of the earth. Those that stayed, with their awareness

Eddie Madril, MA (Pascua Yaqui) is Professor of American Indian Studies at San Francisco State University and College of Marin.

Sara Moncada, MA (Yaqui) is a Native educator, dancer, filmmaker, author and cultural arts advocate. 
of the coming future, became bigger beings in the world, became stronger and became the Yoemem bloodline.

We have heard variations of this origin story throughout our lives, and yet each time we encounter them, we are reminded of the importance of remembering; we are born of the sun, we are born of a sacred sound, we contain the knowledge of the language of creation in our ancestral memory, and our relatives are in the natural world all around us, in the sea ania, guiding us and singing us into the future.

In the United States of America (USA), it is no secret that the relationship between Native peoples and the federal government has been one of contention and conflict. Throughout the history of the colonies, the government's drive to secure land and resources has resulted in hard fought battles and wars both on the ground and in political policy. The development of policies to rid the country of its 'Indian Problem' meant sanctioned programmes aimed at removing Indigenous people from their lands and forcing assimilation: banning such things as speaking Native language, making it illegal to practice in traditional songs and dances and to grow traditional foods. There was a constituted goal of fully eradicating the Natives by the turn of the 19th century. In 1892, the Indian Boarding School director Captain Richard Pratt $(1840$ - 1924) spoke about this new regime in a speech at George Mason University that reflected the social, political and cultural policies of the US, famously saying: 'In a sense, I agree with the sentiment, but only in this: that all the Indian there is in the race should be dead. Kill the Indian in him, and save the Man' (Carlisle). During this time, known as the 'Reservation Period', there were extreme cultural transformations. From language, songs, dances and clothes, to foods eaten and accepted spiritual practice and understanding, assimilation in most cases meant survival as human beings. It meant walking hand-in-hand with hard decisions on how to survive culturally.

The biology of who we are as Hiaki is made from the land, the natural world resources in our original environment. It is impossible to talk about our lifeways without also referencing the land of our homes. It is fair to say that the seeds of our ancestors are made from the seeds of our land. From stories, to songs, weaving patterns in textiles to pottery design, to know our people is to know the Sonoran Desert environment. Amongst many products from our traditional environment, there are a few that hold particular significance, especially 
found in the dances and songs of our people: for example, the notable 'shaking tree' that plays a significant role in Yaqui origin stories and original instructions. The tree, the natural world around it, the people's relationship and responses to the voice of the tree, our ceremonies have these original relationships embedded in the songs, the dances, and the regalia. For example, original instruments such as drums, reeds and rasps were made from materials found in the natural landscape, reproducing sounds that echoed the environment around them. However over time, singers began incorporating newer instruments, brining new sounds that could be found in the landscape of a modern world. In recent times the musicians have included violins and guitars; these instruments have become respected as 'traditional', and important aspects of ceremonies today weave them into the fabric of our culture, sharing the old teachings with new sounds.

Yaqui deer songs, maso bwikam, are a traditional song form that is usually sung by three singers accompanied by a deer dancer. The deer dancer, an iconic symbol for Yaqui people, is known as saila maso or little brother deer, and the song and dance teachings are a representation of his voice. This voice and these songs are considered to be the oldest. Yaqui deer singer Felipe Molina and folklorist Larry Evers together have produced some of the most comprehensive texts on Yaqui song, music and dance in the world. In their book Yaqui Deer Songs (1987), they explore the role of deer songs and deer dancers in a living tradition and the contexts in which they continue to move forward into the future. 'Yaquis have always believed that a close communication exists among all the inhabitants of the Sonoran desert world in which they live: plants, animals, birds, fishes, even rocks and springs. All of these come together as part of one living community [. . .]', they write, adding: 'Yaquis regard song as a special language of this community, a kind of "lingua franca of the intelligent universe"' (Molina 18).

The Yaqui Deer Dancer holds gourd rattles made from gourds of the desert. There are large brown moth cocoons wrapped around the dancer's legs below the knee; they shake against each other for a percussive sound during the dance movements. There is a deer's head fastened to the top of the dancer's head. The dancer does not merely mimic the physical actions of a deer, but rather embodies the spirit and personality of the deer. While the deer dance honours the 
animal and its relationship with the people, it is also a cultural inheritance. Contained within the forms is a reminder of a deep connection to our original traditions.

As ceremony, song, and dance grew over time, Chapayeka Dancers - those that bring forward a spirit and representation of supernatural beings full of chaos and disorder - joined the Deer Dancers. In some ways, Chapayeka Dancers represent humans without a spiritual foundation in a new world. Chapayeka societies made their appearance after the coming of the Spanish and more notably, the Jesuits. The formation of such new figures in the cultural narrative became necessary in telling our living history - one that is not static and is continuously evolving.

What becomes essential in the practice of dances and songs then is how they reflect the identity of the people as they see themselves in context in an evolving world. The re-telling of origins as they necessarily engage with the ongoing transformations of life becomes, by definition, 'traditional'. Embedded within the making of the instruments, the making of the regalia, the words sung, the music played, and the movements of the dances, is the history and observance of life as it has happened, and continues to happen, for the people. Yaqui song itself is the vibration of the shaking tree; it has the vibration of that creation sound that comes directly from the voices of our ancestors. Yaqui song is a living anthology of the continued work of telling the history as it is expressed through the lived experience of the people from time immemorial to the present. From sunrise to sunrise, morning-to-morning, the songs and dances are life, understood, as it should be lived.

Towards the end of the $19^{\text {th }}$ Century, tensions between American Indian nations and the federal government were high and becoming more visible. As the government worked towards their goal of eradicating the 'Indian Problem' by the turn of the century, there were some U.S. citizens who began to empathize with the plight of the Indians and their survival. In 1894, a sculpture titled 'The End of the Trail' by James Earle Fraser was first modelled. Based on the words of an old Dakota trapper - 'The Indians will someday be pushed into the Pacific Ocean' (Vittoria) - the sculpture depicted the 'Indian' as slumped and defeated with no positive hope in sight. The final version of the sculpture was a major attraction at its debut in the 1915 Panama-Pacific International Exposition in San Francisco. A moving and evocative image for many, the sculpture gained in popularity. Replicas were commissioned 
en masse, and it continues to be a popular image even today. This iconic image reflected a stereotypical 'Indian' that was seen by non-Native Americans as a true image of all Indians for many generations into the later part of the $20^{\text {th }}$ century and even now. This sculpture represented the success of a colonial power in its regulation of a people, disavowing them, as they were subordinate. At the same time, it also drew attention to their dire condition and the viewers' need to have sympathy.

Within the same time period, as Native Americans were working to find ways to survive both as individual tribes and nations and also as a larger group of Indigenous peoples, came the advent of the popular Wild West shows. Non-native American citizens would often read about 'wild' Indians (as described in most articles and literature), and they would go to the Wild West shows expecting to see a primitive, and savage people. It was disappointing to audiences when the Indian performers instead appeared to be mild mannered, reserved, quiet and even professional. To address the social grumblings, the shows exaggerated, changing the image of the 'Indian' lifestyle, clothing and dance in order to fit the desires of paying audiences. The Wild West shows presented 'Indians' in a variety of performances including horseback riding, mock battles with cavalry soldiers, and Native dancing. Outside the Wild West shows, most dances by most tribes include some aspect of spirituality, religion, or ceremony. Many of these dances are done continuously for many days and with great reverence; therefore to be sustainable, the dances are not very physically active. Because such performances appeared unentertainingly subdued or calm to an uninformed audience in the Wild West shows, the dances took on new movements with new purpose. Faster dance, higher footwork, and more competition style movements became normalized. A new 'tradition' was created.

Soon thereafter, during the 'Termination Period' post WWII, the U.S. government's relocation programme took effect. American Indians were encouraged to move to cities and assimilate into Western society. This programme was a deterrent from having to address American Indian issues and concerns during a time of national pride and patriotism. Native people making their way into cities came up against the abrupt reality that they were not seen as Americans. They were not warmly welcomed. Neither did they find themselves surrounded by people like them with similar worldviews and 
cultural practices, even amongst other Natives, those who had migrated earlier and in so doing had detached themselves from their origins. Many wanted to return home but had no means to do so; they were given a one-way bus ticket with no guarantees of a job or even a place to live after the first thirty days.

In the cities, many Natives converged into locations that would provide a safe space with a familiar sense of community. They created Indian centres for supporting job preparedness, social and cultural knowledge in the urban setting, and the security of being amongst other Native folk. Powwows - Native gatherings with songs and dances primarily of the Plains region of the U.S. - became a way of coming together for Native people living in areas far removed from reservations and traditional lands. This became known in academic arenas as the 'pan-Indian' movement. Thus, a new identity, and new traditions, once again were created.

The modern powwow is a gathering of many people from a wide variety of tribal affiliations, coming together to dance, rejoice, and define. There are a variety of ways in which Native American people talk about powwows and their meaning; however all agree that they are gatherings that were created with the intention to heal and reconnect. Through the sharing of cultural traditions such as song and dance, stories and language, they become a circle of sharing that brings back together the disbursed and dislocated.

Men's Fast \& Fancy dance came into being as a 'contemporary' fabrication during this time. It was created as a dance that could visually and viscerally transmit a message: that of agency and continued recognition of the importance of traditional art forms in metamorphosis. As such, Men's Fancy, has arguably become one of the most visually recognized forms of Native American men dancing. From the outside, Men's Fast \& Fancy can be recognized globally for the (truly beautiful) image it presents of 'traditional' Native dance, and 'authentic' Native men dancing. For Native American people, the dance instils a sense of connection, cultural pride, and identity even though it is a newish practice, born from the legacy of dances created during the Wild West shows and brought forward into the powwow dance area. It is a form of resilience to create such traditions in a modern context.

We are traditional dancers in a new world; new seeds are planted that allow us to cultivate and carry forward the voices of ancestors. As new ways of being Native in the world are 
explored, the languages of traditional song and dance become a cultural currency of resilience. These forms challenge our voices, our relationships with our cultural identities, our interconnections in this world. As we develop new arts voices, what and how we juxtapose traditional aspects, how they are given or performed, how and where they are received, the songs and music that accompany them, these become vital to our ways of knowing who we are as a Native people. Each of these songs, of these dances lies at the fulcrum of what may be construed as both traditional and modern. Indigenous song and dance are a living form of exploration and investigation that not only reflect the life journey of an individual, but also that of the entire community. Performance is a voice of the people, a language of body and movement that allows us to exist in this world and expand and contract in living relationships. Our arts are deeply rooted and embedded inside of expressions of self, community and tradition, holding in sacred space the essential nature of creation and connection.

Traditional performing arts are created as a means of expression, as an accessible platform upon which voices of all kinds can stand. The performing arts can be seen and heard by a wide and diverse audience, commanding attention and empowering individuals and communities alike. Almost by its very nature, art is activism in its ability to, through the voice of the artist, call for change and transformation. When expressing, these dances and songs draw an audience of willing viewers and participants into the message, cultivating a community around the performance that shares time, history, space and - tradition. 


\section{References}

Carlisle Indian School Digital Resource Center. "Kill the Indian, and Save the Man": Capt. Richard H. Pratt on the Education of Native Americans. Archives \& Special Collections WaidnerSpahr Library Dickinson College. Online. 12 Nov 2018. http://carlisleindian.dickinson.edu/teach/kill-indian-andsave-man-capt-richard-h-pratt-education-native-americans.

Evers, Larry and Felipe S. Molina. Yaqui Deer Songs, Maso Bwikam; A Native American Poetry. University of Arizona Press, 1987. Print.

King, Thomas. The Truth About Stories: A Native Narrative. CBC Massey Lectures. CBC Radio Canada, 2003. Audio.

LaMothe, Kimerer L. Why We Dance: A Philosophy of Bodily Becoming. New York: Columbia University Press, 2015. Print.

Murphy, Jacqueline Shea. The People Have Never Stopped Dancing: Native American Modern Dance Histories. University of Minnesota Press, 2007. Print.

Rosenberg, Bruce A. 'The Complexity of Oral Tradition'. Oral Tradition 2.1 (1987): 73-90. Print.

Perea, John-Carlos. Intertribal Native American Music in the United States: Experiencing Music, Expressing Culture. Oxford University Press, 2014.

Vittoria, Shannon. End of the Trail, Then and Now. The Metropolitan Museum of Art. Online. 19 February 2014. Accessed 21 July 2018.

Eddie Madril, MA (Pascua Yaqui) is a professor of American Indian Studies at San Francisco State University and College of Marin. $\mathrm{He}$ is founder and director of Sewam American Indian Dance, Co-Chair of the Board of Directors for World Art West a cultural performing arts non-profit, and has served on the advisory committee for Native Programming at the de Young Museum in San Francisco for over a decade. He is co- 
author of the book The Dance of Caring: A Caregivers Guide to Harmony (Acutrack 2016).

Sara Moncada, MA (Yaqui) is a Native educator, dancer, filmmaker, author and cultural arts advocate. She is VP of Programs at The Cultural Conservancy an Indigenous rights organization, co-founder of Wise Women Circles a womenowned inspirational media company, and director/artist/educator with Sewam American Indian Dance. She speaks internationally on Native American arts and culture, and is producer of the internationally successful film Nurses: If Florence Could See Us Now (2013) and the new podcast series The Native Seed Pod. 